\title{
ICHTHYOFAUNA DIVERSITY IN A PROTECTED AREA IN THE STATE OF SÃO PAULO, SOUTHEASTERN BRAZIL
}

\author{
GOMIERO, L. M. and BRAGA, F. M. S. \\ Departamento de Zoologia, Instituto de Biociências, Universidade Estadual Paulista (UNESP), \\ C. P. 199, CEP 13506-900, Av. 24-A, 1515, Rio Claro, SP, Brazil \\ Correspondence to: Leandro Muller Gomiero, Departamento de Zoologia, Instituto de Biociências, \\ Universidade Estadual Paulista (UNESP), C. P. 199, CEP 13506-900, \\ Av. 24-A, 1515, Rio Claro, SP, Brazil, e-mail: leanmg@ rc.unesp.br \\ Received May 5, 2004 - Accepted August 8, 2004 - Distributed February 28, 2006
}

(With 4 figures)

\begin{abstract}
The study site is located in an environmentally protected area known as an "APA" in São Pedro and Analândia, State of São Paulo, southeastern Brazil, whose watercourses are under strong anthropogenic pressure. Two basins were studied (sub-basin of the Corumbataí River and basin of the Jacaré-pepira River) with the purpose of characterizing the ichthyofauna of various streams, comparing fish diversity among assemblages. The Passa-cinco River showed the highest diversity (H'), and the Jaccard and Morisita-Horn indices showed low similarity among sites and between the basins. Diversity was correlated with the number of available habitats and with the environmental conditions.
\end{abstract}

Keywords: diversity, ichthyofauna, APA of São Pedro and Analândia.

\section{RESUMO}

\section{Diversidade da ictiofauna na área de Proteção Ambiental das cuestas de São Pedro e Analândia (SP)}

A região abordada encontra-se na Área de Proteção Ambiental das cuestas de São Pedro e Analândia, interior do Estado de São Paulo, com grande ação antrópica em seus cursos d'água. Duas bacias foram estudadas (sub-bacia do Corumbataí e bacia do Jacaré-pepira), com o objetivo de caracterizar a ictiofauna de alguns ribeirões, enfocando comparativamente a diversidade de suas comunidades ictíicas. A diversidade (H') verificada no Rio Passa-cinco foi a maior, e os índices de Jaccard e Morisita-Horn mostraram baixa similaridade entre os locais de coletas e entre as bacias. A diversidade foi relacionada à quantidade de habitats disponíveis e às condições gerais de cada ambiente.

Palavras-chave: diversidade, ictiofauna, APA de São Pedro e Analândia.

\section{INTRODUCTION}

The Neotropical region is particularly interesting because it is a refuge for fish speciation (Mazzoni \& Lobón-Cerviá, 2000). In Brazil, the second most important basin in terms of area and fish diversity is the Paraná-Paraguai-Uruguai (Prata) basin, which contains approximately 500 species. However, the species composition in this basin is little known. Furthermore, its ichthyofauna has been severelyimpactedbymanydeleteriousanthropogenic activities (Casatti et al., 2001). According to these authors, fish populations in the upper Paraná basin have also been undergoing major alterations caused by large-scale environmental degradation resulting from the construction of dams, uncontrolled use of pesticides and fertilizers, deforestation - mainly of the riparian forests, siltation, and introduction of species from other basins. 
Several fish populations have declined owing to anthropogenic activities; thus, human actions may lead to diverse community simplification (Lowe-McConnell, 1990).

Some types of changes and variations in their intensity may benefit some species by increasing their chances for survival and reproduction. Other species, however, may be affected to different degrees according to their particular traits (Barrella et al., 2001). A decline in species richness is one of the inevitable consequences (Magurran \& Phillip, 2001). However, diversity may be a good indicator of environmental changes (Barrella \& Petrere Jr., 2003).

Fish diversity in rivers is related to habitat complexity, which is influenced by depth, type of substratum, and water current velocity. The more pristine the river, the greater and more stable the species diversity throughout the seasons. The relationship between habitat traits and presence or absence of fish species suggests that the majority of fishes in small streams are habitat specialists (Gorman \& Karr, 1978). Ecological studies focusing on biodiversity patterns are crucial for the management and conservation of natural resources in the tropics (Galacatos et al., 1996).

The main objective of this study was to characterize the ichthyofauna of the streams in two basins (Jacaré-pepira basin and Corumbataí sub-basin), which are located in an environmentally protected area (APA) in São Pedro and Analândia, state of São Paulo, Brazil, and to compare fish diversity among sites.

\section{MATERIAL AND METHODS}

A total of 12 samplings were made bimonthly, from February to December of 2000 and 2001. Each sampling period lasted five days.

The study region is located in an environmentally protected area on the cuestas of São Pedro and Analândia. The protected area (APA) is situated between the latitudes $22^{\circ}$ and $23^{\circ} \mathrm{S}$ and the longitudes $47^{\circ} 30^{\prime}$ and $48^{\circ} 30^{\prime} \mathrm{W}$. Part of the area lies within the Peripheral Depression and the other on the basaltic cuestas, both in the interior of the state of São Paulo in southeastern Brazil. Altitude tropical climate (CWa) predominates in the region, which is characterized by mean annual temperatures ranging $18^{\circ}$ to $22^{\circ} \mathrm{C}$, with warm wet summers and dry winters. Rainfall varies from $1,400 \mathrm{~mm}$ in the upper regions to $1,100 \mathrm{~mm}$. The study area of approximately $2,700 \mathrm{Km}^{2}$ comprises part of the municipalities of Itirapina, Brotas, São Pedro, Dois Córregos, Santa Maria da Serra, Torrinha, São Carlos, Analândia, Ipeúna, Mineiros do Tietê, Rio Claro, Barra Bonita, Corumbataí, and Itaqueri da Serra.

After a preliminary analysis of the region, we selected two study sites: 1) Corumbataí River sub-basin, with four sampling sites: Cabeça River (point 1) - 22 $22^{\prime} 49^{\prime \prime} \mathrm{S}, 47^{\circ} 39^{\prime} 55^{\prime \prime} \mathrm{W}, 601 \mathrm{~m}$ of altitude, Lapa Stream (point 2) - 22 23 ' $38^{\prime \prime}$ S, $47^{\circ}$ 47 ' 16" W, $633 \mathrm{~m}$ of altitude, Passa-cinco River (point 3) - $22^{\circ} 25^{\prime} 02^{\prime \prime} \mathrm{S}, 47^{\circ} 42^{\prime} 47^{\prime \prime} \mathrm{W}, 567 \mathrm{~m}$ of altitude, and Corumbataí River (point 4 ) - $22^{\circ} 08^{\prime}$ $15^{\prime \prime} \mathrm{S}, 47^{\circ} 39^{\prime} 37^{\prime} \mathrm{W}, 615 \mathrm{~m}$ of altitude; and 2) Jacaré-pepira River basin, with three sampling sites: Tamanduá Stream (point 5) - 22 $22^{\prime} 17^{\prime \prime} \mathrm{S}, 47^{\circ}$ $45^{\prime} 00^{\prime}$ ' W, $642 \mathrm{~m}$ of altitude, Jacaré-pepira River (point 6) - 22 $2^{\circ} 17^{\prime} 53$ ' S, $48^{\circ} 11^{\prime} 35^{\prime}$ ' W, $490 \mathrm{~m}$ of altitude, and Água Branca Stream (point 7) - $22^{\circ}$ $26^{\prime} 20^{\prime \prime} \mathrm{S}, 48^{\circ} 47^{\prime} 45^{\prime \prime} \mathrm{W}, 841 \mathrm{~m}$ of altitude.

At each sampling point, individuals were collected from many points in the water course, using $5 \times 1.5 \mathrm{~m}$ gill nets with mesh sizes of 1.5 , 2.0, 2.5 and $3.0 \mathrm{~cm}$ spacing between adjacent knots. Each set of nets covered an area of $30 \mathrm{~m}^{2}$. In addition to the nets, $1.5 \mathrm{~m}$ high purse seines with mesh sizes of $1.5 \mathrm{~cm}$, as well as sieves and traps, were used whenever possible.

The sampling work was standardized to a constant time and number of fishing instruments employed at each point. The gill nets were left submerged from the early evening to the following morning. The specimens retrieved from the nets were then placed in plastic containers containing $10 \%$ formalin. Each container was labeled with the date and sampling site number. The fishes were identified in the laboratory down to the lowest taxonomic level.

Diversity was verified through the Shannon index, which was calculated for each sampling point. This index assumes that each individual is sampled randomly from an infinitely large population and that all species are represented in the sample. The index $\left(\mathrm{H}^{\prime}\right)$ is given by:

$$
\mathrm{H}^{\prime}=-\sum \text { pi. } \ln \mathrm{pi}
$$


The sum of pi is the proportion of individuals found among these species. The equitability (E) can also be calculated, indicating the abundance of species at each point. The closer to 1 , the greater the similarity among species abundances; if the value reaches 1 , the species abundance is equal.

The Jaccard similarity index, which takes into account the presence or absence of a species, and the Morisita-Horn index, which also takes species abundance into account, were also used (Magurran, 1991).

The Jaccard index is used to compare species similarities between two sites. This index is given by:

$$
C_{j}=\frac{J}{(a+b-j)}
$$

where:

$\mathrm{j}$ is the number of species found at both sites, $\mathrm{a}$ is the number of species recorded at site $\mathrm{A}$, and $\mathrm{b}$ is the number of species recorded at site $\mathrm{B}$.

This index assumes that if the calculated value equals 1 , the two sites show a total similarity of species and, if the value is zero, there is no similarity.

The Morisita-Horn index is also used to compare similarity, but is more sensitive to species richness and sample size. This index is given by:

$$
\begin{aligned}
& C_{M-H}=\frac{2 \Sigma\left(a n_{i} \cdot b n_{i}\right)}{(d a+d b) a N \cdot b N} ; \quad d a=\frac{\Sigma a n_{i}^{2}}{a N^{2}} \\
& \text { and } d b=\frac{\Sigma b n_{i}^{2}}{b N^{2}}
\end{aligned}
$$

where:

$\mathrm{aN}$ : total number of individuals at site $\mathrm{A} ; \mathrm{bN}$ : total number of individuals at site $\mathrm{B}$; $\mathrm{an}_{\mathrm{i}}$ : number of individuals of species (i) at site $\mathrm{A}$; and $\mathrm{bn}_{\mathrm{i}}$ : number of individuals of species (i) at site B.

These indices were used for comparisons between sites and between basins. Similarity matrices were constructed using these indices and a Cluster Analysis was then performed using the UPGMA method (Valentin, 1995).

\section{RESULTS}

A total of 4,050 specimens belonging to 48 species and 13 families were caught and analyzed. Families and species names, with their respective occurrence sites, are listed in Table 1.

The Shannon (H') index of diversity and equitability (E) was calculated for each sampling site; the highest value was found for the Passa-cinco River (Corumbataí basin), followed by the Jacaré-pepira River (Jacaré-pepira basin), while the Água Branca Stream displayed the lowest value.

The sites exhibiting the highest equitability (E) were the Cabeça River and the Jacaré-pepira River, while the Água Branca Stream showed the lowest value.

Table 2 shows the values of H', E, and the number of species recorded at each site.

A comparison of the Corumbataí and Jacaré-pepira basins revealed low Jaccard and Morisita-Horn indices of 0.52 and 0.21 , respectively. Thus, the ichthyofauna in these basins exhibited low similarities.

A comparison of the two basins' seven sites showed highly varying indices. The Jaccard similarity index varied from 0.03 to 0.52 , with an average of 0.32 . On the other hand, the Morisita index varied from 0.0006 to 0.61 , with an average of 0.24 .

These sites exhibited generally low similarity. The Água Branca Stream showed the lowest indices compared with other sites, while the Lapa Stream and the Passa-cinco River displayed the highest similarity values (Figs. 1 and 2).

A cluster analysis based on the Jaccard and Morisita-Horn indices grouped the Lapa Stream and Passa-cinco River under the highest similarities. The Água Branca Stream, in contrast, showed the lowest similarity (Figs. 3 and 4).

\section{DISCUSSION}

The Neotropical freshwater ichthyofauna is extremely rich and diverse, with 2,400 to 5,000 species already described (Rosa \& Menezes, 1996). This fauna comprises mostly characoids and siluroids, which underwent fantastic adaptive radiation initiated in the Tertiary System during the long period of South American isolation (Lowe-McConnell, 1999).

The state of São Paulo contains about $30 \%$ of the known Brazilian fish species, with 261 freshwater species distributed as follows: 53\% Siluriforms, 35\% Characiforms, 4\% Gymnotiforms, 
TABLE 1

Species captured and their occurrences at each sampled site (1. Cabeça River; 2. Lapa Stream; 3. Passa-cinco River; 4. Corumbataí River; 5. Tamanduá Stream; 6. Jacaré-pepira River; and 7. Água Branca Stream).

\begin{tabular}{|c|c|c|c|c|c|c|c|c|}
\hline Family & Species & 1 & 2 & 3 & 4 & 5 & 6 & 7 \\
\hline Loricariidae & Hypostomus strigaticeps & $*$ & $*$ & $*$ & $*$ & $*$ & $*$ & \\
\hline Cichlidae & Geophagus brasiliensis & $*$ & $*$ & $*$ & $*$ & $*$ & & $*$ \\
\hline Curimatidae & Steindachnerina insculpta & $*$ & $*$ & $*$ & & $*$ & $*$ & \\
\hline Characidae & Astyanax altiparanae & $*$ & $*$ & $*$ & $*$ & $*$ & $*$ & \\
\hline Characidae & Astyanax scabripinnis & $*$ & $*$ & $*$ & $*$ & $*$ & & \\
\hline Parodontidae & Apareiodon affinis & & $*$ & $*$ & & & $*$ & \\
\hline Crenuchidae & Characidium aff. zebra & $*$ & $*$ & $*$ & $*$ & $*$ & $*$ & \\
\hline Loricariidae & Rineloricaria latirostris & & $*$ & $*$ & & & $*$ & \\
\hline Characidae & Piabina argentea & $*$ & $*$ & $*$ & $*$ & & & \\
\hline Loricariidae & Hypostomus ancistroides & $*$ & $*$ & $*$ & $*$ & & $*$ & \\
\hline Loricariidae & Hypostomus albopunctatus & & & $*$ & & & & \\
\hline Pimelodidae & Rhamdia quelen & $*$ & $*$ & $*$ & $*$ & $*$ & & $*$ \\
\hline Pimelodidae & Pimelodella sp1. & & $*$ & $*$ & $*$ & & $*$ & \\
\hline Callichthyidae & Corydoras flaveolus & & $*$ & $*$ & & & $*$ & \\
\hline Anostomidae & Leporinus friderici & & & $*$ & & & $*$ & \\
\hline Poeciliidae & Poecilia reticulata & & & $*$ & $*$ & & & \\
\hline Parodontidae & Apareiodon ibitiensis & & & & $*$ & & & \\
\hline Parodontidae & Parodon tortuosos & & & $*$ & $*$ & & $*$ & \\
\hline Characidae & Serrapinus cf. notomelas & $*$ & $*$ & & $*$ & $*$ & & \\
\hline Characidae & Astyanax fasciatus & & $*$ & $*$ & $*$ & $*$ & $*$ & \\
\hline Cichlidae & Oreochromis niloticus & & $*$ & & & & & \\
\hline Loricariidae & Hypostomus spl. & $*$ & $*$ & $*$ & $*$ & & $*$ & \\
\hline Characidae & Salminus hilarii & & & & & $*$ & $*$ & \\
\hline Characidae & Acestrorhynchus lacustris & & & & & & $*$ & \\
\hline Loricariidae & Loricaria piracicabae & & & & & & $*$ & \\
\hline Pimelodidae & Pimelodella sp2. & & & & & & $*$ & \\
\hline Erythrinidae & Hoplias cf. malabaricus & $*$ & $*$ & & & $*$ & & $*$ \\
\hline Poeciliidae & Phalloceros caudimaculatus & & $*$ & $*$ & & & & $*$ \\
\hline Characidae & Astyanax spl. & & $*$ & $*$ & & & $*$ & $*$ \\
\hline Callichthyidae & Hoplosternum littoralis & $*$ & & & & & & \\
\hline Loricariidae & Hisonotus sp. & & $*$ & $*$ & $*$ & & $*$ & \\
\hline Characidae & Galeocharax knerii & & & & & & $*$ & \\
\hline Loricariidae & Hypostomus sp2. & & $*$ & & & & $*$ & \\
\hline Callichthyidae & Corydoras aeneus & $*$ & & & $*$ & & & \\
\hline Pimelodidae & Imparfinnis mirini & & $*$ & & & & & \\
\hline Sternopygidae & Eigenmania cf. trilineata & & $*$ & & & & & \\
\hline Loricariidae & Hypostomus regani & & $*$ & $*$ & $*$ & $*$ & $*$ & \\
\hline Characidae & Serrapinus heterodon & $*$ & & $*$ & & & $*$ & \\
\hline Loricariidae & Corumbataia cuestae & & & $*$ & & & & \\
\hline Curimatidae & Cyphocarax modestus & $*$ & & & & & $*$ & \\
\hline Characidae & Bryconamericus sp. & & $*$ & & & & & \\
\hline Loricariidae & Hypostomus cf. regani & & & & & $*$ & & \\
\hline Characidae & Odontostilbe microcephalus & & & $*$ & & & & \\
\hline Doradidae & Rhinodoras dorbignyi & & & & & & $*$ & \\
\hline Characidae & Astyanax sp2. & & & & $*$ & & & \\
\hline Loricariidae & Rineloricaria sp. & & & $*$ & & & & \\
\hline Anostomidae & Leporinus obtusidens & & & $*$ & & & & \\
\hline Anostomidae & Schizodon nasutus & & & & & & $*$ & \\
\hline
\end{tabular}


TABLE 2

N) Species number; H') Shannon diversity index; and E) equitability at each sampled site (1. Cabeça River; 2. Lapa Stream; 3. Passa-cinco River; 4. Corumbataí River; 5. Tamanduá Stream; 6. Jacaré-pepira River; and 7. Água Branca Stream).

\begin{tabular}{|c|c|c|c|c|c|c|c|}
\hline Sites & $\mathbf{1}$ & $\mathbf{2}$ & $\mathbf{3}$ & $\mathbf{4}$ & $\mathbf{5}$ & $\mathbf{6}$ & $\mathbf{7}$ \\
\hline Families & 08 & 11 & 10 & 08 & 08 & 09 & 05 \\
\hline $\mathrm{N}$ & 16 & 26 & 28 & 19 & 13 & 26 & 05 \\
\hline $\mathrm{H}$ & 2.07 & 2.09 & 2.38 & 1.79 & 1.46 & 2.38 & 0.77 \\
\hline $\mathrm{E}$ & 0.40 & 0.29 & 0.35 & 0.33 & 0.28 & 0.44 & 0.10 \\
\hline
\end{tabular}

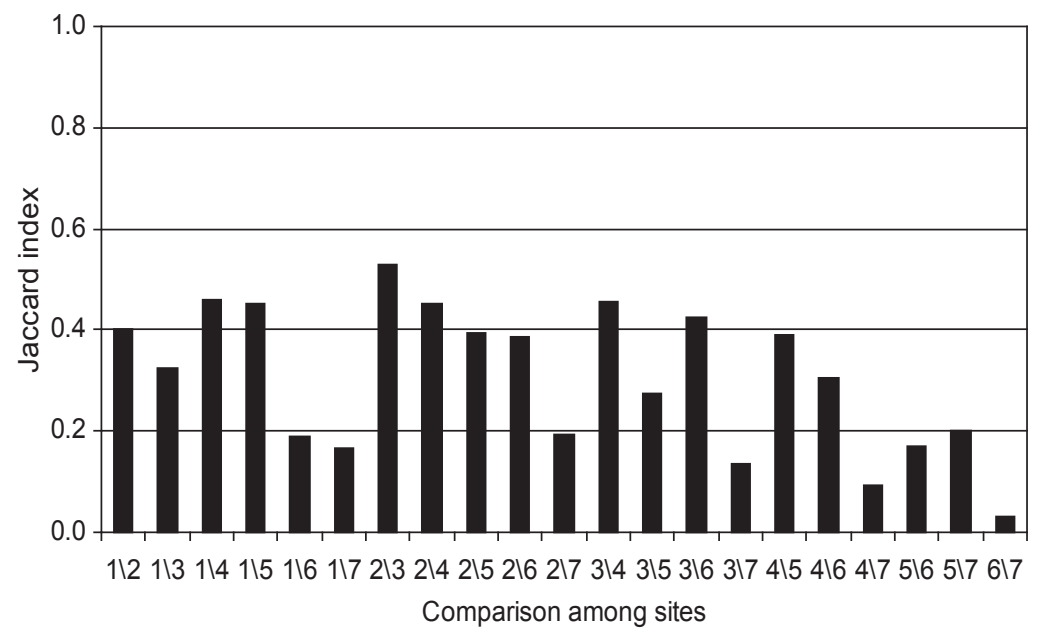

Fig. 1 - Jaccard similarity index for study sites in both basins (1. Cabeça River; 2. Lapa Stream; 3. Passa-cinco River; 4. Corumbataí River; 5. Tamanduá Stream; 6. Jacaré-pepira River; and 7. Água Branca Stream).

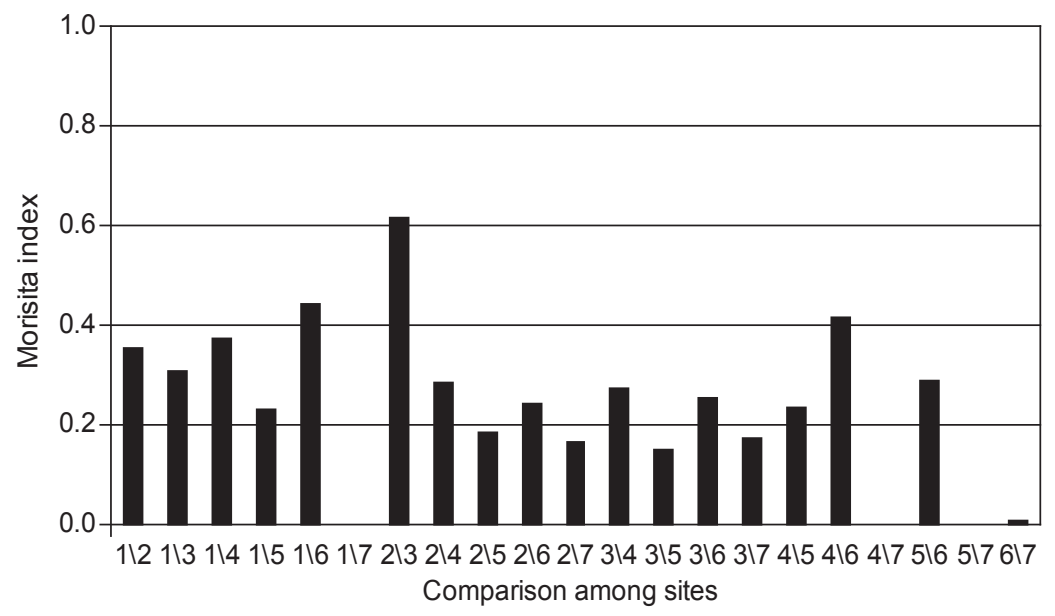

Fig. 2 - Morisita similarity index for study sites in both basins (1. Cabeça River; 2. Lapa Stream; 3. Passa-cinco River; 4. Corumbataí River; 5. Tamanduá Stream; 6. Jacaré-pepira River; and 7. Água Branca Stream). 


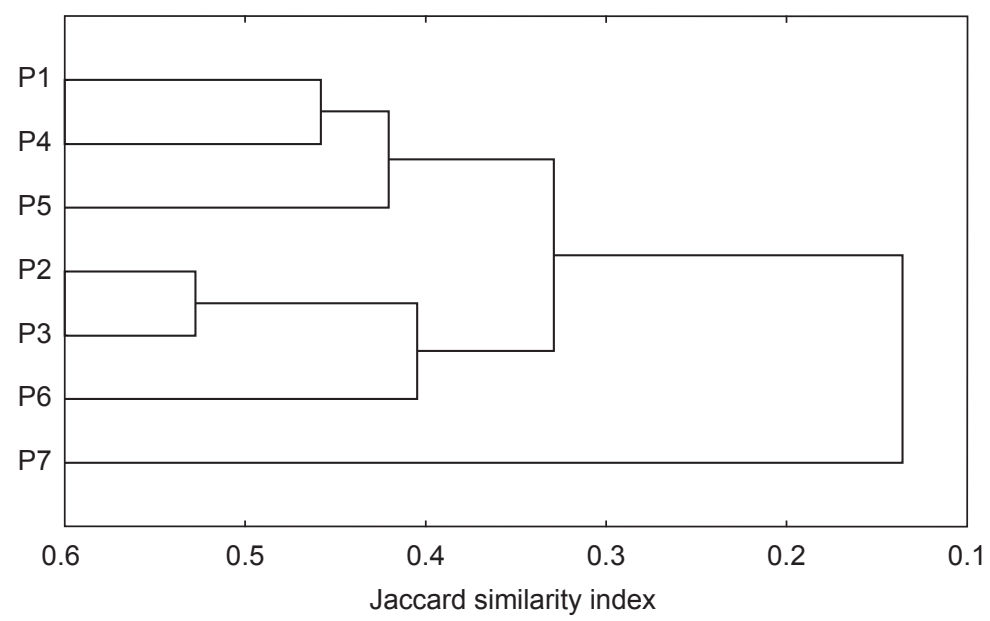

Fig. 3 - Cluster analysis of study sites based on the Jaccard similarity index (P1. Cabeça River; P2. Lapa Stream; P3. Passa-cinco River; P4. Corumbataí River; P5. Tamanduá Stream; P6. Jacaré-pepira River; and P7. Água Branca Stream).

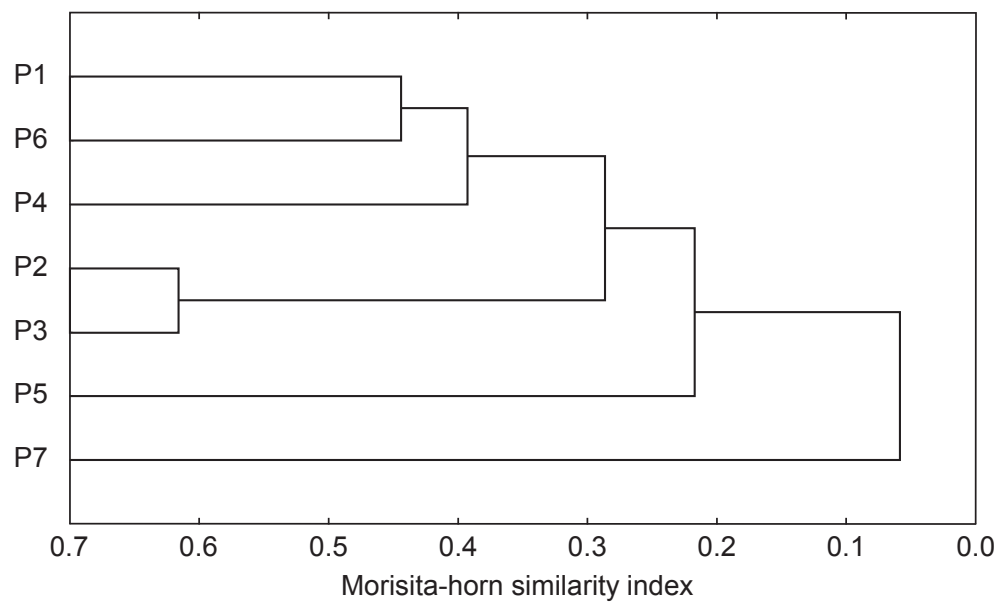

Fig. 4 - Cluster analysis of study sites based on the Morisita-Horn similarity index (P1. Cabeça River; P2. Lapa Stream; P3. Passa-cinco River; P4. Corumbataí River; P5. Tamanduá Stream; P6. Jacaré-pepira River; and P7. Água Branca Stream).

5\% Cyprinodontiforms, and 3\% Perciforms. Most of the state of São Paulo is located in the Upper Paraná River basin, which contains 22 fish families and approximately 166 fish species (Castro \& Menezes, 2001).

The fish families recorded in this study were: Characidae, Crenuchidae, Parodontidae, Curimatidae, Anostomidae, Erythrinidae, Sternopygidae, Pimelodidae, Doradidae, Callichthyidae, Loricariidae, Poeciliidae, and Cichlidae.
About 34 teleost fish families occur in Brazil's streams (Buckup, 1999). All the families captured in the present study have stream-typical species except for Doradidae. This family occurs only in the Jacaré-pepira River, a water body devoid of any stream-like characteristics.

According to Buckup (1999), Characidae is not stream exclusive and its members generally form the main group in midwater. The Crenuchidae family includes small species that inhabit streams. Some of these species prefer calm waters but others 
dwell in rapid or even extremely rapid waters, and C. zebra may occur in a variety of habitats ranging from calm to rapid waters (Buckup \& Reis, 1997). Parodontidae are found mainly in streams. Curimatidae are microphagous and can inhabit streams with gently flowing waters. Anostomidae include small size species that are always associated with submerged vegetation in streams. Erythrinidae are common in streams and spend the day hiding in dense vegetation, leaving at night to catch prey. Sternopygidae are nocturnal and are always associated with vegetation. Callichthyidae is very frequent in streams. The small "cascudos" of the subfamily Hypoptopomatinae occur predominantly in streams, where they inhabit the submerged marginal vegetation (Britski, 1997). Poeciliidae exhibit internal fertilization and are very common in stream meanders. Cichlidae are highly diversified and are also present in streams.

Although ecological knowledge of stream fish assemblages is still incipient, the frequency of species occurrence appears to be influenced by its preference for certain sites, its ontogenetic stage, and the seasonal plasticity of each habitat (Lemes \& Garutti, 2002a).

Congruent with Uieda's findings (1984), the most abundant species were present at the sampling sites throughout the study period, the most frequent being the families Characidae and Loricariidae. Lemes \& Garutti (2002b) and Casatti et al. (2001) observed similar species distribution in streams, with a predominance of Siluriformes and Characiformes. Peres-Neto (1995) captured mainly fishes of the family Loricariidae in the Macacu River, state of Rio de Janeiro, Brazil.

The Água Branca Stream contained large amounts of submerged aquatic vegetation. The largest capture in quantitative terms occurred here, mainly involving the families Characidae and Poeciliidae. Casatti et al. (2003) obtained similar results, finding a predominance of small characids amidst aquatic macrophytes, and increasing species diversity in the winter.

The rivers Passa-cinco and Jacaré-pepira displayed the highest diversity indices. Samples were taken in the midcourses of these rivers, which presented gallery forests and more microhabitats than other sites.

The characteristics of a system, such as physical heterogeneity or seasonality, are very important in determining species flexibility (Zaret, 1982). In certain regions, seasonal fluctuations in the water level are the most important environmental factor, affecting the fish assemblage (Kushlan, 1976). However, diversity is more affected by mean differences or by constancy in environmental conditions among sites than by seasonal variations in these conditions (Ostrand \& Wilde, 2002).

The greatest diversity is found in river midcourses (Vannote et al., 1980), where communities use all the available niches (Gatz Jr., 1979). These regions are characterized by great habitat availability and low fluctuation in environmental conditions (Schlosser, 1985; PeresNeto et al., 1995).

Another important factor influencing diversity is the presence of gallery forests. These forests are important for the dynamics of aquatic ecosystems, providing habitats and shelters, shady areas, migration corridors, reproduction sites, and organic material. Furthermore, gallery forests may help diminish the siltation process, regulate water flow rate, water chemical concentration, thermal and energy flow, and river bank contention (Barrella et al., 2001). Habitats with gallery forests presented high heterogeneity in fish coexistence, which is explained by the presence of marginal areas in the forest fragments, increasing habitat structural heterogeneity (Amaral \& Petrere Jr., 2001). Moreover, submerged marginal vegetation provides food, shelter and substratum diversity. Microhabitat availability increases with river size and this was probably the main factor differentiating the Cuesta (higher area) from the Peripheral Depression (lower area), as reported by Barreto \& Uieda (1998).

The Água Branca Stream showed the lowest diversity index. This site is situated at the stream's headwaters upstream from a more than 10-m-high waterfall. The stream contains large amounts of decomposing organic matter and is devoid of gallery forest, with pasture areas predominating.

The diversity is greater in less seasonal communities. In the rivers, diversity decreases as the latitude increases and seasonal fluctuations in water level are more pronounced. Diversity also decreases with altitude; toward the headwaters, the physicochemical conditions, presence of waterfalls, high water flow velocity, and refuge size 
and conditions in the dry season may constitute more limiting factors than food resources (Lowe-McConnell, 1999).

Low diversities are expected in headwaters due to the great variability in water flow and discharge, which may represent abiotic control of the population (Peres-Neto, 1995). Factors determining the lower limit of individual species also determine species diversity (Sheldon, 1968).

Topographic barriers (e.g., falls) and high declivity are factors that affect species movements (Barreto \& Uieda, 1998), preventing recolonization of headwaters by species from low areas. According to Horwitz (1978), this may occur following heavy rains. However, if these areas exhibit minimal conditions and are isolated, they may favor speciation (Balon \& Stewart, 1983).

Diversity usually increases from the headwaters toward the estuary, as a result of the addition of species (Kuehne, 1962; Sheldon, 1968; Horwitz, 1978). However, the differences found in streams in Colorado, USA, which were analyzed with the Jaccard coefficient and the Morisita similarity index, were due mainly to the absence of rare species at certain sites rather than to the addition of species (Lohr \& Faush, 1997). In natural streams, highly diverse assemblages are more stable throughout the year (Matthews et al., 1998). However, that is not the case in modified streams with low diversity (Gorman \& Karr, 1978). In the Cedro Stream (SP), the occurrence of species, habitat occupation, and population structure may change throughout the year (Lemes \& Garutti, 2002b).

Equitability in natural communities may be low (Silva, 1999). Pollution is the main factor responsible for reducing species richness and increasing the predominance of some species (Magurran \& Phillip, 2001; Barrella \& Petrere Jr., 2003). Furthermore, the number of less abundant species is directly proportional to the water volume, while the relative predominance of species is inversely proportional to this volume (Garutti, 1988).

The two drainage basins showed little similarity due to considerable habitat variability and differences in their environmental conditions. The sampling sites also showed low similarities; the Água Branca stream showed the lowest indices due to its particular location (upstream from a waterfall) and the surrounding conditions. The Lapa Stream and the Passa-cinco River displayed the highest similarity indices. These water bodies are in geographic proximity and their environmental characteristics were similar. Dias \& Garavello (1998) found that the most environmentally and physicochemically similar sites displayed the highest Jaccard similarity index. Interspecific interactions are also very important in determining the geographical distribution and abundance of species (Gilliam et al., 1993).

Our data suggest that variability in environmental conditions influenced the diversity of species at each site by increasing microhabitats.

Some species predominated at more disturbed sites (Cabeça and Corumbataí River), or more isolated ones (Água Branca Stream); hence, diversity was lower. Both basins and study sites revealed low similarities, which can be explained by the great variability in habitats and differences in environmental conditions.

Acknowledgments - L. M. Gomiero is indebted to FAPESP (Brazil) for the graduate fellowship granted to him. Thanks are also due to IBAMA (Brazil) for conceding the research permits.

\section{REFERENCES}

AMARAL, B. D. \& PETRERE JR., M., 2001, The $\alpha$ and $\beta$ diversities in the fish assemblages of the Promissão reservoir (SP-Brazil): scales, complexities and ecotone heterogeneity. Ecohydrol. \& hydrobiol., 1(1-2): 185-193.

BALON, E. K. \& STEWART, D. J., 1983, Fish assemblages in a river with unusual gradient (Luongo, Africa-Zaire system), reflections on river zonation, and description of another new species. Env. Biol. Fish., 9(3-4): 225-252.

BARRELLA, W. \& PETRERE JR., M., 2003, Fish community alterations due to pollution and damming in Tiête and Paranapanema Rivers (Brazil). River Res. Applic., 19: 59-76.

BARRELA, W., PETRERE JR., M., SMITH, W. S. \& MONTAG, L. F. A., 2001, As relações entre as matas ciliares, os rios e os peixes. In: Matas Ciliares. Conservação e recuperação. Eds: Rodrigues e Leitão Filho, Edusp, 320 p.

BARRETO, M. G. \& UIEDA, V. S., 1998, Influence of the abiotic factors on the ichthyofauna composition in different orders stretches of Capivara river, São Paulo State, Brazil. Verh. Internat. Verein. Limnol., 26: 2180-2183.

BRITSKI, H. A.,1997, Descrição de um novo gênero de Hypoptopomatinae, com duas espécies novas (Siluriformes, Loricariidae). Pap. Avul. de Zool., 40(15): 231-255.

BUCKUP, P. A., 1999, Sistemática e biogeografía de peixes de riacho. In: Ecologia de peixes de riachos. Série Oecologia Brasiliensis, $6^{\circ}$ vol., PPGE-UFRJ, Rio de Janeiro, Brasil, 
Eds. E. P, Caramaschi, R., Mazzoni, \& P. R., PERESNETO, pp. 91-138.

BUCKUP, P. A. \& REIS, R. E., 1997, Characidiin genus Characidium (Teleostei, Characiformes) in Southern Brazil, with description of three new species. Copeia, 3: $531-548$

CASATTI, L., LANGEANI, F. \& CASTRO, R. M. C., 2001, Peixes de riacho do Parque Estadual Morro do Diabo, bacia do alto rio Paraná, SP. Biota Neotropica, 1: 1-15.

CASATTI, L., MENDES, H. F. \& FERREIRA, K. M., 2003, Aquatic macrophytes as feeding site for small fishes in the Rosana Reservoir, Paranapanema River, Southeastern Brazil. Braz. J. Biol., 63(2): 213-222.

CASTRO, R. M. C. \& MENEZES, N. A., 2001, Estudo diagnóstico da diversidade de peixes do Estado de São Paulo. Disponível em: <http://www.biota.org.br/ iLink?livros.biota+Peixes+volseis+Diagnostico $>$. Acesso em: 17 set. 2001.

DIAS, J. H. P. \& GARAVELlO, J. C., 1998, Ecological studies on the fish community of Salto Grande reservoir, Paranapanema River basins, São Paulo, Brazil. Verh. Internat. Verein. Limnol., 26: 2228-2231.

GALACATOS, K., STEWART, D. J. \& IBARRA, M., 1996, Fish community patterns of lagoons and associated tributaries in the ecuadorian Amazon. Copeia, 4: 875-894.

GARUTTI, V., 1988, Distribuição longitudinal da ictiofauna em um córrego da região noroeste do Estado de São Paulo, bacia do rio Paraná. Rev. Brasil. Biol., 48(4): 747-759.

GATZ JR., A. J., 1979, Community organization in fishes as indicated by morphological features. Ecology, 60(4): 711-718.

GILLIAM, J. F., FRASER, D. F. \& ALKINS-KOO, M., 1993, Structure of a tropical fish community: a role for biotic interactions. Ecology, 74(6): 1856-1870.

GORMAN, O. T. \& KARR, J. R., 1978, Habitat structure and stream fish communities. Ecology, 59(3): 507-515.

HORWITZ, R. J., 1978, Temporal variability patterns and the distributional patterns of stream fishes. Ecol. Monograp., 48(3): 307-321.

KUEHNE, R. A., 1962, A classification of streams, illustrated by fish distribution in an eastern Kentucky Creek. Ecology, 43(4): 608-614.

KUSHLAN, J. A., 1976, Environmental stability and fish community diversity. Ecology, 57: 821-825.

LEMES, E. M. \& GARUTTI, V., 2002a, Ecologia da ictiofauna de um córrego de cabeceira da bacia do Alto rio Paraná, Brasil. Iheringia, 92(3): 69-78.

LEMES, E. M. \& GARUTTI, V., 2002b, Ictiofauna de poção e rápido em um córrego de cabeceira da bacia do Alto rio Paraná. Comun. Mus. Ciênc. Tecnol., 15(2): 175-199.

LOHR, S. C. \& FAUSCH, K. D., 1997, Multiscale analysis of natural variability in stream fish assemblages of a western great plains watershed. Copeia, 4: 706-724.

LOWE-McCONNELL, R. H., 1990, Summary address: rare fish, problems, progress and prospects for conservation. J. Fish Biol., 37(Supl. A): 263-269.
LOWE-McCONNELL, R. H., 1999, Estudos ecológicos de comunidades de peixes tropicais. Editora da Universidade de São Paulo, São Paulo, 535p.

MAGURRAN, A. E., 1991, Ecological diversity and its measurement. Chapman and Hall, London, 179p.

MAGURRAN, A. E. \& PHILLIP, A. T., 2001, Implications of species loss in freshwater fish assemblages. Ecography, 24: 645-650.

MATTHEWS, W. J., HOUGH, D. J. \& ROBISON, H. W., 1998, Similarities in fish distribution and water quality patterns in streams of Arkansas: congruence of multivariate analyses. Copeia, 2: 296-305.

MAZZONI, R. \& LOBÓN-CERVIÁ, J., 2000, Longitudinal structure, density and production rates of a neotropical stream fish assemblage: the river Ubatiba in the Serra do Mar, southeast Brazil. Ecography, 23: 588-602.

OSTRAND, K. G. \& WILDE, G. R., 2002, Seasonal and spatial variation in a prairie stream-fish assemblage. Ecol. Fresh. Fish, 11: 137-149.

PERES-NETO, P. R., 1995, Estrutura de comunidades de peixes ao longo de um gradiente lótico de um rio costeiro do leste brasileiro (rio Macacu, RJ). Dissertação de Mestrado, Universidade Federal do Rio de Janeiro, RJ, 81p.

PERES-NETO, P. R., BIZERRIL, C. R. S. F. \& IGLESIAS, R., 1995, An overview of some aspects of river ecology: a case study on fish assemblages distribution in an eastern Brazilian coastal river. In: Oecologia Brasiliensis. Estrutura, funcionamento e manejo de ecossistemas brasileiros, UFRJ, Esteves, F.A. (ed.), 1: 317-334.

ROSA, R. S. \& MENEZES, N. A., 1996, Relação preliminar das espécies de peixes (Pisces, Elasmobranchii, Actinopterygii) ameaçadas no Brasil. Rev. Bras. Zool., 13(3): 647-667.

SCHLOSSER, I. J., 1985, Flow regime, juvenile abundance, and the assemblage structure of stream fishes. Ecology, 66(5): 1484-1490.

SHELDON, A. L., 1968, Species diversity and longitudinal succession in stream fishes. Ecology, 49(2): 193-197.

SILVA, C. P. D., 1999, Estrutura, dieta e padrão longitudinal da comunidade de peixes de dois rios da Estação Ecológica da Juréia-Itatins e sua regulação por fatores bióticos e abióticos. Tese de doutorado em Ecologia, UNICAMP, SP, $134 \mathrm{p}$.

UIEDA, V. S., 1984, Ocorrência e distribuição dos peixes em um riacho de água doce. Rev. Brasil. Biol., 44(2): 203-213.

VALENTIN, J. L., 1995, Agrupamento e ordenação. In: P. R., Peres-Neto, J. L., Valentin, \& F. A. S. Fernandez. (Ed.). Tópicos em tratamento de dados biológicos. Rio de Janeiro: UFRJ, pp. 27-55.

VANNOTE, R. L., MINSHALL, G. W., CUMMINS, K. W., SEDELL, J. R. \& CUSHING, C. E., 1980, The River Continuum Concept. Can. J. Fish. Aquat. Sci., 37(1): 130137.

ZARET, T. M., 1982, The stability/diversity controversy: a test of hypotheses. Ecology, 63(3): 721-731. 